\title{
Hamka's Doctoral Address at Al-Azhar: The Influence of Muhammad Abduh in Indonesia
}

\section{KEVIN W. FOGG}

University of Oxford, United Kingdom

Email: kevin.fogg@history.ox.ac.uk

\section{ABSTRACT}

This is a translation of the doctoral address given by Haji Abdul Malik Karim Amrullah (Hamka) when he received a doctorate honouris causa from al-Azhar University. Although Hamka assigned his talk the title 'The Influence of Muhammad Abduh in Indonesia', the primary topic is actually the evolution of Islam in Indonesia and the development of Islamic reformism and the address minimally touches on the Egyptian thinker. For the 1950s, this can be taken as a normative, indigenous view of Indonesia in an Islamic, especially reformist, context.

Keywords: Islamic reformism, Indonesian Islamic History, Hamka.

\section{ABSTRAK}

Naskah ini adalah terjemahan (Bahasa Inggris) dari pidato Haji Abdul Malik Karim Amrullah (Hamka) ketika beliau dianugrahi gelar doktor honouris causa dari Universitas al-Azhar. Walaupun Hamka mencantumkan judul 'Pengaruh Muhammad Abduh di Indonesia', sebenarnya pidatonya menceritakan perkembangan Islam di Indonesia dan pembangunan Islam reformis; perhatian terhadap pemikir Mesir itu ternyata sangat sedikit. Untuk tahun 1950an, pidato ini bisa dianggap gambaran normatif dari penduduk asli Indonesia mengenai Indonesia dari perspektif Islami umumnya dan reformis khususnya.

Kata Kunci: Reformasi Islam, Sejarah Islam Indonesia, Hamka.

\section{INTRODUCTION}

Haji Abdul Malik Karim Amrullah (1908-81), better known by his acronymic name Hamka, was a unique figure in modern Indonesian intellectual history. As Indonesian literary critic Farchad Poeradisastra wrote, 'it would be easy to find clerics more learned, better writers abound, but there is no comparable 
figure in Indonesian history (with even half his talents) who attempted to bridge the literary and religious realms'. ' Born to a prominent Islamic cleric in the Minangkabau heartland of West Sumatra, he travelled throughout the 1920s and 1930s for religious activism and journalism, and then became a prominent figure on the national stage from the 1950s until his death, particularly through his activism in the Islamic mass organization Muhammadiyah.

Hamka's most famous work on religious themes might be Tasauf moderen (Modern mysticism), compiled initially in 1939 from a series of articles written in previous years. ${ }^{2} \mathrm{He}$ also contributed to Indonesian popular history through his memoir about his father, entitled Ayahku (My father, 1950), and his autobiography in four volumes, Kenang-kenangan hidup (Life recollections, 195152), both of which were well-received and built up Hamka's national reputation. ${ }^{3}$ In his young days he helped to pioneer literary modernism in his journal Pedoman Masjarakat (Society's guide) published from Medan, ${ }^{4}$ in his later years he founded and edited the journal Panji Masyarakat (Society's standard)..$^{5}$ In both religion and literature, Hamka was strongly influenced by the cultural renaissance that occurred in the Arab world around the turn of the twentieth century. ${ }^{6}$ In this address given when he received a doctorate honoris causa from al-Azhar University in Cairo, often seen as the pinnacle of Islamic educational institutions, Hamka focused on that Arab influence on the religious generation that came just before him.

The speech translated here was delivered in Cairo on 21 January 1958, when Hamka received an honorary doctorate from al-Azhar. Muhammad Abduh (c. 1849-1905), the ostensible subject of this address and personification of Arab Islamic modernism, actually receives very little attention in the speech, presumably because the audience would already have been quite familiar with him. Abduh was a theologian and activist, who grew up in Egypt but then experienced several periods of exile (to Beirut and to Paris) before coming back to positions of great influence in the 1890s, including Mufti of Egypt (the country's leading Islamic juridical authority) from 1899. Abduh also had strong connections to al-Azhar University, including having studied there in the 1860s and sitting on its administrative council from 1895, making it natural that Hamka would choose him for the title of this address in order to draw in his audience. Abduh's contributions to Islamic life in the Middle East were not only religious but also institutional, in education, Islamic courts, and Islamic journalism, particularly through the journals he edited: al-'Urwa al-Wuthqa (from Paris, with Jamal al-Din al-Afghani), and al- 
Manar (from Cairo, carried on by his disciple Rashid Rida). ${ }^{7}$ The echoes to Indonesia, however, were mainly in religion. He was focused on the challenge of modernity to Islamic theology and society, recognising a gap between the European-oriented progress of his age and the Islamic heritage to which so many Egyptians still clung. Abduh sought to close this gap 'by accepting the need for change, and by linking that change to the principles of Islam: by showing that the changes which were taking place were not only permitted by Islam, but were indeed its necessary implications if it was rightly understood, and that Islam could serve both as a principle of change and a salutary control over it'. ${ }^{8}$ This spirit came to Indonesia in the early twentieth centry, but there it took on a different kind of life in social organizations and education, as Hamka describes below.

Although Hamka had never studied at al-Azhar University, his connection with that institution was a very important one for him. His exegesis of the Qur'an —written largely while imprisoned under Soekarno — was entitled Tafsir al-Azhar in a fairly clear reference to the university, ${ }^{9}$ and he focused his community activities in the South Jakarta al-Azhar Mosque, ${ }^{10}$ which blossomed during the late twentieth century into several kinds of social outreach, including a school also called al-Azhar. The honourary doctorate that occasioned this speech cemented Hamka's relationship with the great Egyptian institution and must have been one of the highlights of his life.

The history Hamka presents here of Islamic reformism in Indonesia is not entirely new. ${ }^{11}$ However, this account stands out for coming from an individual who was closely tied to the main actors (inter alia, Hamka moves his own father to a very central role, which is only partly justified) and also a key part of the movement in its later stages. The speech also provides insight into how an Indonesian Muslim in the early independence period saw his country in the context of the wider Islamic world. Although several aspects could be subject to academic dispute, this can be safely taken as a normative indigenous view of Indonesia in an Islamic, and particularly reformist, context.

\section{The Translation: ${ }^{12}$ Explaining Muhammad Abduh in His Country}

Respected attendees!

The entrance of Islam to our homeland of Indonesia, which previously was commonly known as 'the East Indies Archipelago', differed quite a bit from its entrance to other countries. The light of Islam reached our country 
not because it was brought by a particular mission or army. If the history of Islam's entrance into Egypt here began with the arrival of Sayyid Amr ibn alAsh and the entrance into Africa was because of the arrival of Sayyid Okbah bin Nafi', and its entrance in to Andalucía was because Tariq ben Ziad crossed the sea headed straight for the mountain which would later be named for him, and its entrance into India came with the arrival of Muhammad bin Qasim, then the one who brought Islam to Indonesia is 'the Unknown Hero'!

Those who brought the holy torch of Islam to Indonesia were a community of merchants who, besides their business of buying and selling, immediately spread the Islamic religion. As you all know, the trade relationship between India and China is already quite old, passing through the Red Sea [sic] and the Straits of Malacca. Because of that, one cannot identify precisely the era, year, and date of the beginning of Islam's entrance into Indonesia.

There are historians who say that during the reign of Yazid bin Muawiyyah, the second Umayyad caliph, there was a group of Arab families who made it to the West Coast of Sumatra, meaning less than one hundred years after our Prophet Muhammad (SAW) passed away. But in the third and fourth centuries hijriyyah, in the golden age of the reign of Bani Abbas in Baghdad, there were already many sailors and travelers of the Arab nation who spoke of the island of Sumatra, when they spoke of a Buddhist monarchy that was known in their books by the name of 'Sharbazah', or the Kingdom of Sriwijaya which was located in Palembang, the modern-day capital of South Sumatra.

But after that Indonesia fell under the heel of Dutch colonialism, and they [the Dutch] held that Islam entered Indonesia in the thirteenth century AD, because in that century the Islamic Kingdom of Pasai, Aceh, was founded. Truly this has already become the customary way to organize classical history, beginning history with the foundation of a kingdom. Nevertheless it is already a known fact that never was there a kingdom established before there was a society.

In the fourteenth and fifteenth centuries $A D$, an Islamic kingdom was founded and flourished on the peninsula of Malaya, namely the Kingdom of Malacca. Simultaneously the Islamic Kingdom of the Moluccus was also founded (which at that time encompassed West Irian [Papua], as well), which was based in Ternate. And before that, as I said earlier, the oldest was the Kingdom of Pasai in Aceh.

But at the beginning of the sixteenth century, that is in the year 1511, that hated race which was foremost among the Christian kingdoms in the Cru- 
sades and which had already destroyed the Islamic kingdom in al-Andalus, the Portuguese nation attacked Malacca, until it fell. And at the end of that century (that is, in the year 1596), the Dutch entered the port at Bantam, which was the location of the founding of the beautiful Islamic Kingdom of Bantam, which was located on the western end of the island of Java. After that, one by one [local kingdoms] were infiltrated by their influence and they subjugated the people, sometimes by violence and sometimes by trickery, not only on Java and Sumatra but on other islands, as well.

So with all their strength and effort, trickery and ruses, they worked to stop the influence of Islam which had become the basis of the strength of the Indonesian nation, either by sword or by other means. So over a period of 442 years in peninsular Malaya (which achieved independence this past August 31, 1957), and 350 years in Indonesia, they tried to extinguish the light of Islam; but God did not want this, but rather He perfected His light, no matter how the infidels resisted.

\section{Respected Gentlemen!}

After the arrival of the Portuguese who opened the door, a wave of other colonialists came: Dutch, French, English, and Spanish in the Philippine Islands. We struggled for almost four centuries to stay alive; we struggled to defend our religion so it would not die under the influence of that foreign power of a different religion. All kinds of things were taken by force from our hand, from the power of our kings to the wealth of our fertile land and the inheritance of our ancestors, until there was only one thing left for us, that which they were not able to take from us, that is our Faith and belief which was deep and firm, that is 'There is no God but God and Muhammad is the Prophet of God!'

This was our torch, which lit the path for us to Freedom and Independence. And in the end we achieved both; thanks be to God! After the Crusades and after the destruction of the Kingdom of Bani 'Abbas in Baghdad at the hands of the Mongols and Tartars and after the sad story of the Muslim community in Spain, it can be said that Islam has undergone bitter experiences, and the light of the Sun of Islam nearly faded in all of the Islamic World. But we of the Indonesian and Malay nations suffered more miserably and more bitterly, because when it comes to the grip of colonialism, it was we who suffered first, before the other Islamic countries. And the only weapon left to us, as I said earlier, was merely Islam, which is being faithful to God! 
But where could we find that touchstone of holding firm in faith? As it happens, our country is located far from the centers of activity in Islam. And the Islamic world itself which we want to hold up as our model had already fallen as well into a deep chasm because of the stagnation of thinking. At that time there were incorrect techings of Sufi orders that brought obstinance and self-surrending, which taught 'Mutu qabla an tamutu' (Die before death), and held sway everywhere. ${ }^{13}$ And our enemies were not satisfied before all of our strength was destroyed. And traces of the teachings of the old religions, whether Brahmanistic or Buddhist, also had not been entirely lost.

Although that was our fate in that time, nevertheless time and time again rebellions broke out against colonialism, and the leaders were always Islamic heroes. These included, for example, Emir Diponegoro who established an Islamic reign over all of Java; and Tuanku Imam Bonjol, in West Sumatra, the land of the Minangkabau, who was influenced by Wahhabi teachings; and Sheikh di Tiro in Aceh who intended to clean the infidels out of Aceh; and others. All of them used arms to wage war on the foreign government and Dutch colonialism, taking the base of their power from faith in God who would surely help them, immediately or eventually! Because God has promised: 'If you help God, surely God will help you, as well, and strengthen you in righteousness.' So it was that some from among them achieved martyrdom on the field of battle, and some from among them died in exile. The struggle was always discouraging, because the enemies were always greater in number and with more complete weaponry. But they remain everlasting in the memory and soul of the Indonesian nation, and their heroism became a torch shedding light on the path toward glory and independence. And the losses of those heroes almost caused dispair and loss of spirit to appear, but that torch was never extinguished, so as to bring about the dreams of the reemergence of the glory of Islam.

In this particular period a few sons of Indonesia departed for the holy city of Mecca to fulfill the obligation of the hajj and to increase their knowledge of the Islamic sciences. Among them were Sheikh Nawawi of Bantam, Sheikh Ahmad Khatib of Minangkabau and others. They studied exegesis, hadith, jurisprudence, foundations of jurisprudence, and other things. So there were among them some who returned to Indonesia, but they never brought back with them new ideas for revival, because Mecca at that time was still enveloped in the attitude of blind obedience. And their teachers taught that the gates of interpretation had been closed for eternity, because the people of the 
early ages did not leave behind any matters which would be discussed. ${ }^{14}$ And half of them did not want to return to Indonesia, because they could not control their heart looking at their country which had been colonized, so they remained quietly in Mecca until their passing, choosing to die in the Holy Land.

My respected brothers!

This is a picture of our intellectual world, as I elucidate it in front of you: especially for the length of the nineteenth century, an atmosphere pervaded by a deep darkness. The darkness of thought in the end spread, as well, to the political sphere.

Truly! We still had Islamic kings, but those kings were nothing more than tools without any power in the hands of the Dutch authority, to be used to enslave and pressure the Indonesian people. It was nothing to the Dutch to give them magnificent titles, like the titles 'Shah of the World', 'Full Moon of the World', and others, but these titles did not hold any authority whatsoever. It was as though the tongues of the colonialists were busy saying: 'Give me your land, your inheritance and your authority, and I will give you a title in their place.' And they were called by these names in Friday sermons. And besides those kings there were also people called ulama, who were given gifts, given uniforms and occasionally their chests were decorated with stars. And to repay these great favors they gave fatwas which led the people astray, allowing what was forbidden and forbidding what was allowed.

And in contradiction to that there were, as well, the other half of the ulama who had given up their castles in the sky and royal thrones, and they retreated far away, living in frozenness and 'death before death'. They denounced the whole world; the world that was good or the world that was evil, they saw it all with eyes of hate. So they turned the Islamic community away from the whole world because of the turn of those ulama, and their understanding was made incorrect because of the misunderstandings of their teachers. Because of that it was easy for those colonialists to take control of that world which the Islamic community hated. And Islam, as you gentlemen present know, is quite far from that apathetic life and spirit of death; rather, Islam stirs one up to strive, work, do good deeds and struggle, to reach the life which is more joyous and sooner, alongside doing good deeds for the afterlife, as is said in the holy example of our Prophet: 'Work to improve the world as if you are going to live forever and work to improve your afterlife as though you are going to die tomorrow!' 
This situation became even more of a mess after the Dutch government in 1905 passed a law stating that whoever wished to teach the Islamic religion must first get permission from the Dutch government, with certain conditions. Among these conditions, one was that one could not teach a belief that the Imam Mahdi would descend at the end of days and bring back justice to this world, because that teaching was seen as truly dangerous by those in power, since it could open the door for rebellion! ${ }^{15}$

Apart from the picture that I have presented in passing, we can understand how much the faith needed to be purified from the polytheism and innovations and incorrect Sufi teachings, which had already descended upon our country ages ago, and the need for independence of thought and renewal of understanding regarding true Islamic teachings. And from here we can see how important the teachings of Ustadh Imam Sheikh Muhammad Abduh were, those teachings which culminated in independence of thought and interpretation. Political, economic, social and other forms of independences all stem from the foundation of independence of thought. And in Islam the foundation of independence of thought is in the Belief in God's Unity, which liberates humanity from fear and from submission to anything other than God!

\section{The Influence of Muhammad Abduh's Teachings in Indonesia}

\section{The First Pioneer: Sheikh Taher Jalaluddin}

It is the nature of the weather in our country that if it gets very hot in the middle of a pitch-black night, that means that a heavy rain is about to come down.

Thanks be to God! That heavy rain came. The teachings of Sheikh Muhammad Abduh made it to Indonesia. The first pioneer was Sheikh Taher Jalaluddin. He came from the Minangkabau area of Sumatra and from a long line of heroes of Islam who had defended Islam when Western colonialism began to infiltrate that area. He went to Holy Mecca to study deeper into the heart of the Islamic religion. After that he continued his studies in Egypt, at al-Azhar University around $1310 \mathrm{AH}$ (1892 AD), which is when the name of Sheikh Muhammad Abduh was rising in Egypt for his famous work correcting [misperceptions], after he was permitted to return home from his exile in Beirut. 
We have not yet reached my true question: did Sheikh Taher Jalaluddin, who was still young at that time, have an opportunity to be taught in the study group of Sheikh Muhammad Abduh? What is clear is that since the magazine al-Manar was first published in 1315 until that magazine stopped publication, Sheikh Taher Jalaluddin was a loyal subscriber. And after he returned to his homeland, it was the ideas from al-Manar which had become his life's guide. After Sheikh Muhammad Abduh passed away in 1905 (1323 $\mathrm{AH})$, that is to say in 1906 (1324 AH), Sheikh Taher Jalaluddin together with the respected Sheikh Muhammad al-Kalali, a man of Arabic heritage, published the magazine al-Imam in Singapore, whose contents were clearly drawn from the pages of al-Manar. And sometimes plans written by Sayyid Jamal alDin al-Afghani and Sheikh Muhammad Abduh from the magazine al-'Urwa al-Wustqa were translated to Malay and put into that magazine.

In 1908 the leader of that beloved magazine [al-Imam] was forced to leave it, because the Sultan of Perak worked with all his might to get him to accept the position of Mufti in the Kingdom of Perak. His colleagues suggested he take that honorable position, because they felt it had great potential to help him achieve the goals of change and advancement which he held so passionately in his heart.

So he accepted that position and surrendered his leadership of al-Imam to Sayyid Muhammad bin Aqil, and he set off for Perak. When the Sultan of Perak, Sultan Idris Murshidu'l A'zam Shah left for London to attend the accension to the throne of King George V, Sheikh Taher Jalaluddin, in his position as Mufti of the Kingdom of Perak, joined in the entourage of the Sultan.

But that respected position did not actually satisfy his heart. His fatwas were already far ahead of the rulings usually received from the previous Mufti. Eventually, although the Sultan supported him, the other ulama of the Kingdom were not always pleased to receive his rulings, to the point where disputes always arose. In the end that free soul felt that his position as Mufti was only limiting his total freedom, such that he entreated the Sultan to free him from this responsibility. The Sultan was forced to acquiesce and he [Taher Jalaluddin] stepped down, then he left in 1911 for the country of Johor, and he taught there. And in that year the ulama who were of the same mind, or his students from when he was in Mecca, also put out the second Islamic magazine in Indonesia and Malaya, and the first on Sumatra. That was the magazine al-Munir, published in Padang. 
After that he also became the Chief of the Editorial Board of the magazine Saudara [Brother], which was published in Pulau Pinang until 1937. Because of that, in the history of Malay publishing, Sheikh Taher is known as 'the Sheikh of journalists'.

\section{The 'Kaum Muda' on Sumatra}

There were also ulama on Sumatra that received that new movement, the foremost of whom consisted of three men: Sheikh Muhammad Jamil Jambek (who was the oldest among them), Sheikh Abdullah Ahmad and Sheikh Abdul Karim Amrullah. ${ }^{16}$

Sheikh Abdullah Ahmad lived in the city of Padang, and it was he who headed the publishing of al-Munir. Sheikh Abdul Karim Amrullah lived in Padang Panjang, and Sheikh Muhammad Jamil Jambek in Bukittinggi.

Sheikh Jamil Jambek was an expert in astronomy, and he was the one who first held the view that the start and end of the Ramadan fast could be set using calculations [as opposed to observation]. And he was wonderfully skilled in moving the hearts of villagers to be strong in their devotion and to reject false beliefs regarding Sufi orders. And Sheikh Abdul Karim Amrullah was an expert in jurisprudence and the principles of jurisprudence, and he made it clear in one of his books that he opposed the idea that the gates of interpretation were closed. He founded a madrasah in Padang Panjang to shape leaders who would later take his teachings to the people. And Sheikh Abdullah Ahmad was a publisher and journalist, who with his pen spread ideas not only to villagers but to those people who had a Western education. Among his devotees at that time was a youth named Mohammad Hatta! He is now a great leader in Indonesia. ${ }^{17}$

In al-Munir Sheikh Abdul Karim Amrullah answered all sorts of questions regarding religious laws and laid out his respected fatwas, which differed notably from normal understandings.

The first great shock that arose was after Sheikh Abdul Karim Amrullah put out his book, published by the publisher of al-Munir, named al-Fawaidul 'Illiyah; the shock was exclusively for stating that the pronunciation of the intention 'Ushalli' at the beginning of prayers ${ }^{18}$ indeed did not originate with the Prophet and was not performed by his companions nor by the four imams who founded the schools of jurisprudence. He laid out the view of ulama in every school of jurisprudence who supported his view, among them the state- 
ments of Ibnul Qayyim in his book Zadul Ma'ad.

The second shock was after the publishing of another book that was titled Iqazun Niam which stated that it was a religious innovation to stand when chanting on the birthday of the Prophet (peace be upon him). After that he also put out a ruling attacking temporary marriages to allow divorced women to then remarry their original husbands, ${ }^{19}$ even though that horrible pattern was still practiced a lot by people in that time and hushed up by the ulama, that is to say permitted, because the latest ulama of the Shafi'i school permitted it. After that he began to renounce practices of the Sufi community, that is to say he never accepted it when a teacher performed mysticism, and he combated the teaching of the Unity of Existence! ${ }^{20}$

Although these problems arose surrounding the name Sheikh Abdul Karim Amrullah, all the same his two friends joined with him in defending those rulings. And throughout all this other ulama who did not agree with these teachings began to state their support.

Beside that, they began to change Friday sermons. All this time Friday sermons were only given in Arabic. Preachers did not understand the sermons themselves, how much more so the listeners. They put out a ruling that sermons could be given in a language that was understood by the religious community in a given place, and if they were to use Arabic it was enough to use it just for the core principles. This was so that there would be a profit in those sermons which were meant to give direction and teachings to the Muslim community! People have counted as many as seventeen new matters that they put forward.

Clearly there arose a reaction from the ulama who were standing for the old ways. And that reaction was quite strong. Abdul Karim Amrullah and his companions were accused of having left the schools of jurisprudence, that is they had cherry-picked from the schools, because they were using reasoning from the book Zadul Ma'ad of Ibnul Qayyim, who was not a scholar of the Shafi'i school, but of the Hanbali school, and one whose rulings were often found incorrect by other scholars in his time. And if they had cherry-picked from the schools, clearly they had left traditional Sunni orthodoxy.

Because of that, [the opponents] also published a magazine: al-Mizan. They named themselves the 'Kaum Tua' [literally, Old Group] that loyally clung to the school of jurisprudence and gave the new generation of ulama the title 'Kaum Muda' [literally, Young Group] that had left the school.

An exchange of ideas took place, sometimes positive and refined and 
sometimes crude, in those two magazines. Maybe half of the issues of that period can now be seen as unimportant, but in that time they were critical questions, because they were the start of a study that opened thoughts, a sign that the gates of interpretation were beginning to open. Previously the guides people used were only the books Tuhfah and Nihaya, but now they had moved on to al-Um and then to the Qur'an.

In those heated exchanges the books of Sayyid Zaini Dahlan and Sheikh Yusuf Nabhani spread. Those two in their works condemned the ideas of Ibn Taymiyyah and Ibnul Qayyim and condemned the Wahhabis, because of the issue of intercession. And Sheikh Yusuf Nabhani did not condemn them openly, but slandered and insulted Sayyid Jamaluddin al-Afghani and Sheikh Muhammad Abduh, unleashing all of his bitterness in low words that were unfitting for a normal person, so much more so for ulama. Until now there are still some continuing influences from the slander in Nabhani's book in places which are hidden and were not brave enough to accept the light of the Sun of Truth.

The Kaum Muda were accused of leaving the schools of jurisprudence, apeing the infidels because they permitted the wearing of pants and permitted the study of religion using desks and notebooks. But all of those deprecations and attacks did not in any way cause them to retreat a single step backwards, but rather made them even braver.

As I have said, Sheikh Abdul Karim Amrullah taught in Padang Panjang, and quite a few students came. Among those students was Zainuddin Labay El-Junusy, who translated the Biography of Mustafa Kamil into Indonesian in 1916. And he did not fail to consider education for girls, such that he later founded a special madrasa for them. Thus we have Madam Rahmah ElJunusiyah who has come to Egypt this year who was later the chief student among them.

And Madam Rahmah herself later continued that work, until that school today has become one of the models of education for girls in the areas of religion, such that there has arisen an intention from the congregational leader of al-Azhar, Dr Sheikh Abdur Rahman Taj, to found a school of that sort as a part of al-Azhar, for which purpose he has gone there [to the school in Indonesia] himself when he passed by that way.

An example of the bravery of those ulama is on the question of clothing. It was customary for ulama to wear robes and turbans, and they themselves wore robes and turbans. But they put out a fatwa that wearing Western-style 
clothes with a brimmed-hat and a tie is not haram [prohibited], because Islam does not determine what style of clothes to wear; this was just like the fatwa of Sheikh Muhammad Abduh that became famous as the 'Transvaal Fatwa'. ${ }^{21}$

But because the Kaum Tua ulama said that wearing those sorts of clothes was haram, Sheikh Abdullah Ahmad and Sheikh Abdul Karim Amrullah expressly wore trousers, brimmed-hats and neckties for several years. And later after that was no longer a hot issue, they reverted to wearing robes and turbans. And Sheikh Muhammad Jamil Jambek specifically bought a motorbike and rode it himself, and bought a car and drove it himself, something that was 'odd' for ulama according to the views of those times.

He rode these vehicles to go to villages and give lessons and fatwas to the community. Those old ulama even requested fatwas from ulama in Mecca to bring them [the Kaum Muda] down and portray them as leading others astray, because of seventeen issues that they put out. And those fatwas came, however the ulama of Mecca had only heard a one-sided explanation. But there was not an impact on the Minangkabau community, or very little; [the reformists'] influence over the villages was already much greater than the influence of those far-away Meccan ulama. People no longer wanted to commit blind obedience.

Those were the tasks that they worked on, until Minangkabau specifically and Sumatra generally underwent new and fast changes. And now it has become a strong center for Islam.

After those three great ulama, Sheikh Muhammad Jamil Jambek, Sheikh Abdul Karim Amrullah, and Sheikh Abdullah Ahmad, laid that firm foundation, asserting the Salafi school of jurisprudence, holding in high esteem the thoughts of Muhammad Abduh, there came accusations of Wahhabism and the like from their opponents, several other ulama explained the position that sided with them. So it is fitting to mention the names of Sheikh Muhammad Thaib of Tanjung Sungayang, Sheikh Abdullatif Rasyid and his brother Sheikh Mustafa Abdullah of Padang Jepang, Sheikh Abdurrasyid of Maninjau, Tuanku Laut of Lintau, Sheikh Ibrahim bin Musa of Parabek. The latter is the only one still alive.

They received students to study in their various schools. Thus the villages of Padang Panjang, Bukittinggi, Parabek, Padang Japang, and Tanjung Sungayang were full of students who studied religion starting to use a new structure. All the madrasahs were collected in 1918 in an organization named 
'Sumatera Thawalib' [Sumatran Students]. In those madrasahs in 1918 they started to teach people the works of Muhammad Abduh and the exegesis of his disciple Sayyid Rashid Rida and others, until there emerged from those schools a young Islamic generation which had received a new spirit. And some of those individuals went on to study in al-Azhar and Darul 'Ulum in Egypt. Among them were Muchtar Luthfi, Ilyas Ya 'kub, Mahmud Yunus, and others, who after they went home brought a new spirit to our country. So it was that Muchtar Luthfi and Ilyas Ya 'kub published two successive journals in Egypt, to spread the goal of modernization in Indonesia. The first was called Seruan Azhar [The Call of al-Azhar] and the second was called Pilihan Timur [The Choice of the East]. Both ceased publication because the colonial government refused them the opportunity for wide circulation.

Many of the students of those ulama have become important people in Indonesia today. Among them are Madam Rahmah El-Junusiyah, a respected guest of Egypt last year and someone who sits in the Indonesian Parliament; Sheikh Ahmad Rasyid Sutan Manshur, General Head of Muhammadiyah and a member of the Constitutional Assembly; Zainal Abidin Ahmad, Vice Chairman of the Indonesian Parliament; Abdullah Aidid, head of the Indonesian mission in the Kingdom of Jordan; Muhammad Zain Hassan, head of the Indonesian mission in Syria; and Manshur Daud, Indonesian Ambassador to Iraq. Several from among those individuals, when they finished studying with those beloved ulama, continued their studies in Egypt, in the wellspring of the thoughts of Muhammad Abduh. There were some who got degrees from al-Azhar and some from Darul 'Ulum, and there were some who continued at the University of Egypt.

Because they saw the renaissance of new understandings in Minangkabau as so important, several Western Orientalists came themselves to study this phenomenon from close up: Prof Dr Schrieke, a professor in the Netherlands, and Prof K.K. Berg. [The latter] has written his impressions about the 'salafi' movement in West Sumatra in his book Wither Islam?, which was translated into Arabic in 1934 by al-Ustadh Abu Raidah and given the Arabic name Wiyhatul Islam.

\section{Pioneers on Java}

\section{Sheikh Ahmad Soorkati}

Now I will move to speaking about [Muhammad Abduh's] influence on Java. There were three ulama who received those teachings and spread them 
and struggled for them, each in their own field.

The first was Sheikh Ahmad Soorkati As-Sudani, whose ancestry was from the Sudan and who lived for a long time in Medina. Some people say that he left the Sudan after the Mahdi rebellion. ${ }^{22}$ He came to Indonesia at the invitation of the Arab Hadrami community that had settled in Indonesia since the start of the nineteenth century, or long before that. They also played a large role in the spread and strengthening of Islam in Indonesia and in the spread of the Arabic language, because Arabic was their own native tongue. But they could not free themselves at all from stagnation in thought and superstition that they had brought from their countries of origin. Occassionally they also brought the deep and abiding competition between groups in their native countries, between Sadaat and Alawiyin and the Kabili group who took up arms and the groups who, in their tradition, had become obsolescent: the Dhu'afaak.

But there were also a few people who had opened their eyes and been able to free themselves from their back-and-forth disputes, which did not fit with the new spirit of the times, and those people took subscriptions to the magazine Al-'Urwa al-Wustqa, such that among them there was a progressive way of thought. And that magazine was banned from entering Batavia, the center of Dutch governance (now Jakarta!) following the English model, because its contents held seeds that were dangerous for the position of the colonialists. But [the Arab community of Indonesia] was able to receive this magazine by smuggling it from Tuban, a small port in East Java. After that they took subscription to Al-Manar by Sayyid Rashid Rida. Both of these magazines opened the way for the arrival of Sheikh Ahmad Soorkati.

So there began to spread the thinking of Sayyid Jamal al-Din al-Afghani, Sheikh Muhammad Abduh, and Sayyid Rashid Rida in the circles of Arab society in Indonesia. Without a doubt this spread more easily in their circles, because Arabic was their native language. Because of this they proposed the establishment of a group called Al-Irsyad on the basis of Abduh's teachings. This group still exists and holds tightly to its foundation even to this day.

I do not intend to tell the story of conflicts between the Irsyad group, the bringers of those new ideas, and the Arab group who defended the old understandings. Of course, sometimes those conflicts were calm and well-spoken, and sometimes they were harsh. I do not want to tell that story again, because you gentlemen already know that this is the tradition of God between what is old and what is new. 
Sheikh Ahmad Soorkati even left behind students who were Arabs, both those who came from the Hadramaut or Arabic descendents who had some Indonesian blood (because Hadramis generally came to Indonesia without bringing their wives, but rather married with Indonesian women). Among his students was Sayyid Omar Hobais, the Leader of Al-Irsyad and now a member of the Constituent Assembly of the Republic of Indonesia from the Masjumi party. One more former student of his was Sayyid Abdur Rahman Baswedan. $\mathrm{He}$ is the one who began to state clearly that Arab children of Indonesia mothers were indeed not 'foreigners' in that country and were not also a 'minority'. Because of that he suggested to his community to blend into Indonesian society, because they would not be returning to the Hadramaut. I also will not be telling the story to you gentlemen tonight of the resistance faced by Baswedan by the fathers of that group, the native Hadramis in Indonesia, because at that time there was a little bit of a feeling that Arabs had a higher position than Indonesian Muslims, and that they did not want to lower themselves to the position of Indonesian Muslims.

Thus, when the government of the [independent] Republic of Indonesia wanted to reserve seats in Parliament and the Constituent Assembly for minorities, Baswedan opposed this vociferously, and he said, 'We are not a minority in this country. We are Indonesians! We were born here, we eat the produce of this land and drink its water, and we will pass away here, Lord willing! We do not feel there is any difference between us and our brothers of other Indonesian ethnicities, what is more with those of the same religion!'

On the basis of that strong opposition the Government was forced not to reserve seats for the Arab community, and what they had was merely Indonesian Arabs sitting in the Parliament and Constitutent Assembly representing the existing political parties. Among them, A. Rahman Baswedan himself is representing the Masjumi party as a colleague of Omar Hobais, and Hamid Algadri is representing the Indonesian Socialist Party and others are for other parties. And Baswedan, like Omar Hobais, is a leader who is very active in the Masjumi party.

\section{K.H.A. Dahlan and Muhammadiyah}

If Sheikh Ahmad Soorkati was the spreader of Abduh's ideas among the Arab circles, then K.H.A. Dahlan was the spreader in the circles of [indigenous] Indonesians. He was the founder of the organization Muhammadiyah. He was born in Yogyakarta, Central Java, the place of the Sultan of Java's 
capital. He is a descendent of nobles, as well, and his ancestors were among the great men surrounding the Raja, such that the Sultan has given them religious posts, namely to become the Preacher at the Sultan's mosque and to receive the title 'Khatib-Amin'. But after he took a subscription to the magazines al-'Urwa al-Wustqa and al-Manar he got a new understanding of Islam, which was added to by reading the exegesis of Muhammad Abduh and the books of Ibn Taymiyya and Ibnul Qayyim. So gradually he freed himself from the bonds of official posts, and he began to see and pay attention to the fate of the Islamic community of Java from close range. He saw that Islam on Java was in danger! He saw that three great enemies to the spiritual development of the nation had fought the Islamic community, namely ignorance, poverty and suffering, or both internal and external illnesses. As time passed, Islam receded more and more, and there was not a single man among the ulama who was a fit leader to correct the situation. Customs and influences of the religious teachings that the Javanese people had embraced from long before - specifically the Buddhist and Hindu faiths_-had not at all disappeared. Muslim children were put into Dutch schools to ensure their prosperous life in later days, but there was no hope that those Dutch schools could protect the religion in the hearts of those children, such that more and more children educated at [Dutch] government schools increased in numbers who had studied things far from religion. Besides that, the Dutch had opened the door as wide as possible for all kinds of missionaries, Protestant and Catholic, to spread the Christian religion and establish schools as well to receive Muslim students. Based on that, there were many Muslim children who left Islam and embraced Christianity. There was not a movement from Islam itself to balance that trend, and Islamic ulama themselves did not pay much attention to this great problem, but rather quarreled about the Caliphate issue which was small. ${ }^{23}$

From the Sultanate of Yogyakarta, even, expectations were not great, because the influence of the Dutch on the person of the Sultan was already quite strong, as was the influence of old traditions that had been maintained.

They paid attention to the movement of the ulama in West Sumatra. They recognized their efforts, and they took subscriptions to the magazine alMunir. But they felt that taking action on Java was not as easy as it was in Minangkabau [West Sumatra]. On Java the population was several times larger than on Sumatra, and the ratio that knew religion was much smaller, and the power of the Dutch was very great and the influence of the missions organi- 
zations had already entered, whereas in Minangkabau this was not so; and from the Sultan they could not hope for anything. Because of this, there needed to be a more organized religious movement that could rival the organized efforts by the opponents.

Thus [Ahmad Dahlan] founded the Muhammadiyah movement in 1912. And he requested recognition by the Dutch powers.

The goals of the movement were:

1. To promote and encourage teaching and studying on the Islamic religion. 2. To promote and encourage the fullest life according to the Islamic religion for its members.

To reach these goals, it was necessary for Muhammadiyah members to first improve their faith regarding Islam, from superstition and [unlawful] innovations [bid'a], to one founded on the Qur'an and the Sunnah. And it was necessary for those members to raise the level of their faith and clean their souls from all polytheism, and to enliven mutual aid, benevolence, and propagation, so that they could become sincere Muslims. And it was required of members, or of students, that they study the Qur'an and align their life with its teachings, step-by-step, and it was necessary to guard seriously the rituals of faith toward God, from the mandatory things to the suggested (superegatory) things.

At first, he developed his teaching to students in the area of the Kauman district of Yogyakarta, that is the district one always finds in Javanese cities around the mosque. After the souls of those students were full, they were instructed to follow the saying of the Prophet: 'Teach what is from me, even if only one verse!' Later they spread those ideas to other places, at first nearby, and over time to other cities. And they founded branches or sub-branches of Muhammadiyah in those other cities, with goals that did not differ from those at the centre.

The efforts and the diligence of their hearts were seen all across Java. They were received in many ways, as always happens when adapting to the bringers of new ideas. There were those who opposed them and there were those who agreed with them and immediately joined them. There were youth who came themselves on pilgrimage to Yogyakarta and after [Ahmad Dahlan] saw that these youth truly hoped to become the spreaders of these ideas to their homes, he came themselves to the places of those youth. So, without regard for his own health and without regard for his own wealth, he left his own 
neighborhood. He went to Solo, Surabaya, Madiun, Pekalongan, Bandung and Jakarta. As I said earlier, I do not want to explain how great the reaction to him was from the defenders of the old ideas.

He has been accused of being a spoiler of religion, and people say he was once slapped in a council meeting, such that he fell down, and this he took by sticking out his chest [in pride]. The reason was that his heart had already received its medicine, namely the several youths who had added to their religion in depth, such as Mas Manshur of Surabaya, Abdul Mu'thi of Madiun, Muchtar Buchari of Solo, Kartosudarmo of Jakarta and others, who later became the important leaders of Muhammadiyah.

And he himself went to teach the Islamic religion to school children who studied in [Dutch] government schools. Sometimes he asked permission to enter the jails, and teach religion to the criminals. And so he poured out his life to this dream, until all of his posessions were spent and his health was troubled.

My father, Sheikh Abdul Karim Amrullah, told me the story of his awe seeing the struggle of Sheikh Ahmad Dahlan during his first travels to Java, when [my father] became [Ahmad Dahlan's] guest in Yogyakarta. My father said of K.H.A. Dahlan: 'He was a man whose face was very soft, but whose heart was very tough.'

The dreams that [Ahmad Dahlan] planted came to fruition, and branches of Muhammadiyah were founded in Solo, Surabaya, Pekalongan, Garut, and Jakarta and a few other places, each with their own work, because he made the regulations that are still used to this day. A branch would not be officially recognized until it had accomplished something.

Muhammadiyah stood strong, even though only in a few places, and he was sure it would spread even more in the future. But because of that, his wealth was already spent and his health was declining terribly. So he fell illaccording to the doctor's explanation it was because of too much work - and he passed away in 1923, after eleven years of working day and night. He passed away in a state of poverty of worldly goods and richness of good deeds.

After he passed away, his students and followers spread Muhammadiyah beyond Java, to Sulawesi, to Kalimantan, to Belitung Island and to Sumatra. And it spread quite fast in Minangkabau [West Sumatra] after Sheikh Abdul Karim Amrullah on his second trip went to Yogyakarta and studied Muhammadiyah's constitution, and after returning home, he was urged by his stu- 
dents and followers to found that same movement in Minangkabau. People joined the organization in droves and founded many branches there, to the point where it was appropriate to hold the National Muhammadiyah Congress for all of Indonesia in Bukittinggi in 1930. But [Abdul Karim Amrullah] himself did not join the organization.

Today Muhammadiyah is spread across all of Indonesia with all of its constituent parts: to spread Islam through preaching, the Tabligh [Propagation] Division; to spread it through writing, the Taman Pustaka [Literary] Division; for education, the Teaching Division; for women, the 'Aisyiyah Division; for boys, the Hizbul Wathan (Scouting) Division. And 'Aisyiyah also has a Nasyiatul 'Aisyiyah Division [for young women].

This movement does not involve itself in politics, even though K.H.A. Dahlan himself became an advisor to the Partai Syarikat Islam that was led by H.O.S. Cokroaminoto. And its Headquarters until today is in the city of Yogyakarta. And the mantra 'not involving itself in politics' is tightly held to until today. But its members are free to join whichever political parties they like, and they are encouraged, if they want to participate in politics, to choose a party that has Islamic goals. Because of that, the majority of them join the Islamic Political Party Masyumi, and a few join other parties, and there are none who join the Communist Party.

Among the members that have become important men in Indonesia, I will give special mention to the late General Sudirman, the founder and the highest object of imitation of the Indonesian National Army. So, too, Colonel $\mathrm{H}$. Yunus Anis, the Head of Spiritual Education for the Army.

It is only fitting that I note that President Sukarno, when he was exiled by the Dutch to Bengkulu, was an active member and branch leader of Muhammadiyah. So was his wife, Fatimah [sic; usually Fatmawati]. And it is only fitting that our current Prime Minister, Ir. H. Juanda, was also active in Muhammadiyah, particularly in the field of education. I say it is only fitting that I mention them because as it happens I have joined the Masyumi party, which occasionally on politics has a different view from them. On this point, Sheikh Muhammad Abduh was right when he said: 'If an issue gets wrapped up in a political climate, its progress becomes chaos.' So much more so in a scholarly and historical speech like the one I am giving now.

On this past 18 November 1957, Muhammadiyah celebrated its $45^{\text {th }}$ anniversary. President Sukarno and Prime Minister Juanda made a point to be present at the celebration and the President gave a speech, saying, among 
other things: 'I am proud that even I got an education from Muhammadiyah. I hope that my name is not striken from the membership rolls!'

The membership totals are not many, if compared with the supposed numbers of Muslims in Indonesia. The Indonesian nation according to the latest count is 80 million people, 75 million who are Muslim, and the members of Muhammadiyah after a census were only 200,000. The reason for this is that membership is not made easy. The ones who are accepted are those with good morals and good diligence in ritual, and whoever is not complete on these conditions is still called a 'candidate member,' or a follower of the ideology (a sympathizer). And what is most important is the influence of these few members on the wider Islamic society and their good works. All perform works following their intentions (kullun ja'malu'ala syakilatih).

Among Muhammadiyah members who have a spiritual connection with Egypt are Prof. Abdulkahhar Mazakkir, a member of [Muhammadiyah's] Central Leadership and the President of the Islamic University of Indonesia at Yogyakarta, and Dr. H. Mohamad Rasyidi who studied at Kulliyatul Adab, Cairo University, until he receved his M.A., and then achieved a doctorate from the Sorbonne University. At one point he was the Indonesian Ambassador to Egypt, and then to Pakistan, and now he has become a professor at a university in Canada. Also Prof. Farid Ma'ruf, Vice-Chair of the Muhammadiyah Central Leadership, who studied at Darul 'Ulum, Egypt. And if I may, I would like to add my name to this, Abdul Malik ibn Abdul Karim Amrullah, a member of the Muhammadiyah Central Leadership. I admit that I have not studied at either al-Azhar or Cairo University, but the relationship of my soul with Egypt is already old, that is, dating back to when I was able to read books in Arabic, especially books of Sheikh Muhammad Abduh, Sayyid Rashid Rida, and others.

The Head of the Muhammadiyah Movement right now is Syeikh Ahmad Rasyid Sutan Manshur, who is Minangkabau and a student of Sheikh Abdul Karim Amrullah, but after studying the Qur'an, in 1922 he moved to Java where he studied Muhammadiyah under K.H.A. Dahlan, until he became a leader of Muhammadiyah since that time. He was chosen by acclamation by two congresses: the Congress in Purwokerto in 1953 and the Congress in Palembang in 1956. On the basis of this selection he moved from Sumatra to Yogyakarta, the center of the movement. 


\section{Sheikh Ahmad Hassan and Persatuan Islam}

The third man who became a propagator of the ideas of Abduh on Java was Sheikh Ahmad Hassan, who now lives and teaches in Bangil, East Java. A few years ago, he lived in the city of Bandung, which is famous for its AsiaAfrica Conference [in 1955], and he was a teacher as well as the leader of the organization Persatuan Islam. He has many books that he has written in Indonesian, spreading the idea of Islam based on the Qur'an and hadith, waging war on blind obedience and urging freedom of thought, rejection of unlawful innovations and superstition and cleansing the faith from the influence of other teachings. And he has also written an exegesis of the Qur'an, named alFurqan. His struggle to oppose the teachings of Ahmadiyah Qadiani and Lahore are well-known everywhere. And his specialty is the strength of his arguments and his firmness in defending the position that he believes is right.

In 1930 he put out a magazine named Pembela Islam [Defender of Islam], with himself as the leader, and his student Mohammad Natsir as the lead author. So it became famous among those who diligently research the development and struggle of Islam in Indonesia how amazing the fight of that magainze was against the idea of nationalism based on asabiyyah [group feeling, i.e., ethnic solidarity]. It became famous the exchange of ideas between them and the leader Sukarno on the issue of whether the struggle to achieve Indonesian independence was based only on the idea of nationalism, or a struggle that was based on the teachings of Islam, which also involved nationalism, but was broader.

Mohammad Natsir, the Leader of Indonesian Islam, and the Head of the Masyumi Party, was a student of Sheikh Ahmad Hassan, and so, too, was an Islamic leader and member of Parliament and the Constituent Assembly who is famous for his bravery and plain-spoken way of stating his ideas: $\mathrm{H}$. Mohammad Isa Anshary! 'State your ideas plainly' was the main technique of Sheikh Ahmad Hassan and Persatuan Islam!

\section{Translation of Books}

In 1924, Ahmad Hani, a student of Sheikh Ahmad Dahlan, translated the book Ar-Raddu 'Adladdahriyin by Jamal al-Din al-Afghani, because at that time Communism was beginning to grow on Java. After that, he also translated Risalatut Tauhid, the work of Sheikh Muhammad Abduh. Around that time, too, Muhammad Syah Syafi'i translated the first section of the Tafsir 
Ustazul Imam [an exegesis of the Qur'an]. After that it was followed by Abdul Wahid An-Naashiriy translating the first section of the Tafsir al-Manar [Exegesis of the Qur'an by Muhammad Abduh]. And Risalatut Tauhid and Tafsir Ustazul Imam are taught to this day in schools left behind by Sheikh Abdul Karim Amrullah in Sumatra. It is fitting for you gentlemen to ask Maktabah Isa al-Baby al-Halaby [the publisher] how many of those books were sent each month and year to Indonesia, especially to Minangkabau [West Sumatra], before World War II.

\section{The Twilight Days of Those Great Men}

\section{Sheikh Ahmad Dahlan}

One by one they have answered the call of their God, going home to the land that never changes after leaving behind deeds that are good and works that are praiseworthy, except for one man who still lives, and may God extend the life of Sheikh Ahmad Hassan, because truly he was the youngest in age among those and the last to appear.

The one who passed away the earliest by far was Sheikh Ahmad Dahlan. He passed away at the beginning of 1923, after finishing his days and all his weath for the Muhammadiyah movement that he had established. He died in a state of poverty of material goods, but richness of memories and good deeds. He was involved in Islamic schools from elementary, to middle and high schools, and they have founded a College in Padang Panjang, West Sumatra, in 1956. ${ }^{24}$

So, too, have many hospitals and orphanages been named after him. There is not a single city [in Indonesia] that does not have a branch and there is no village that does not have a sub-branch. And the Muhammadiyah movement is one of the largest Islamic religious movements in Indonesia. And in the words of the Islamic fighter, Sayyid Amin Husainy, the Mufti of Palestine, who came to Indonesia for the Asia-Africa Conference: 'Muhammadiyah is the largest Islamic Organization in the world!'25

\section{Dr. Sheikh Abdullah Ahmad and Dr. Sheikh Abdul Karim}

\section{Amrullah and Sheikh Ahmad Soorkati}

There were also Sheikh Abdullah Ahmad and Sheikh Abdul Karim Amrullah; these two once came to Egypt to attend the Caliphate Conference put forward by the ulama of al-Azhar in 1926. And they two had the opportunity to 
come together with Egyptian ulama and their leaders. In the same way, ulama came from other places in the Islamic world: from Turkey, Yugoslavia, Poland, and the Transvaal [South Africa]. They also had the opportunity to exchange ideas about the future of Islam and the Muslim community and the relationship between Egypt and their homeland with Sheikh Husein Wali and Sheikh Bachit al-Muthi'iy. And they had the opportunity, too, to visit the Leader of Egypt at that time: Sa'ad Zaghlul. After listening to their students who had advanced their studies in Egypt, hearing how great their struggle was in their homeland to uphold Islam, it was agreed by Sheikh Athaillah Affendy, the former Mufti of Palestine at that time, and Sheikh Chalil alChalidi, the Director of Islamic Endowments in Iraq, and Sayyid Abdul Aziz as-Sta'alaby, the famous Tunisian leader, to give them the degree Doctor Honoris Causa, because al-Azhar at that time did not yet have regulations for giving that degree. And this proposal was agreed to by Sheikh Husein Wali. Dr. Sheikh Abdullah Ahmad passed away in 1934.

On the other hand, Sheikh Abdul Karim Amrullah, my father, the one from whom I learned manners, and my teacher who planted the spirit of struggle in my breast such that I could become a useful human being, after this man returned home from Egypt, his struggle increased in intensity and his influence increased in its spread and his students increased in their number. Within that, he occasionally would not bow his head to the power of Dutch colonialism. Several times he rejected the regulations that were made by the Dutch government that would hamper the development of Islam. And, as a result, he was exiled from his homeland, the place where he shed his blood, the Island of Sumatra, and sent to Java in 1941. So there appeared a protest from the general opinion of the Muslims calling for that exile to be annulled. In the end, the Dutch government openly recognized in the People's Council [colonial legislature] that he was exiled because his influence was growing more powerful in Minangkabau as time passed, such that he was always making the government's actions to protect public safety more difficult to enact!

Not too long after he arrived in Java, the Dutch government fell and surrendered to the threat of the Japanese army, and from that time Java was controlled by Japan. At that time, he met with his old friend Sheikh Ahmad Soorkati, who had become blind. And Sheikh Ahmad Soorkati told him that one of his two eyes was struck by an illness that hurt quite painfully, and so he was taken to a Dutch doctor. After examining him, the doctor explained 
that to eliminate the pain, the eye on the other side would have to be removed, too. And so the eye that was first sick and the second eye as well were removed, and the illness was entirely gone, but he was left blind and without eyes.

Sheikh Ahmad Soorkati passed away in 1943. After Japan took power, there was established a council of ulama, and it had several meetings. One of the meetings was held in Bandung and my father was among those who were invited. Before the council was opened, it was ordered that all of those in attendance stand up straight and bow down facing the Mikado's Palace in Tokyo.

All of the people stood up straight and undertook to bow because they were being forced and they each wanted to guard their lives, except one person only, my teacher and my father, Sheikh Abdul Karim Amrullah. There was a scuffle because everyone remembered what great danger would come to his person, and the Japanese authorities for their part did not know what to do with him. However, he waited patiently for his fate with calm and poise. The council in the end was disbanded and everyone went back to their homes. After that, many ulama and leaders came to visit him to express their blessings, because he did not surrender to Japan. There were some who plainly said their opinions and there were some who cried, because they were afraid that this issue would bring unseen consequences, even the death penalty. But he remained calm and poised, even grateful after that. This was because every meeting like that, he was no longer invited, because he raised a fuss if he were made to attend under force; however, he would never perform the bow [towards Tokyo].

I came from Sumatra to visit him and kissed his hand [to show respect]. Then I asked, 'Were you not afraid, father, that you would be put to death?'

He answered, 'What your father fears is not death, my child. What your father fears is what comes after death.'

But the Japanese authorities, for their part, did not arrest him and kill him, because they realized how great his influence was among the people.

Dr Mohammad Hatta, a great leader of Indonesia, said 'That was the beginning of the Indonesian people's revolt against the Japanese authority from a spiritual perspective!'

And so there came several people from the Japanese High Command to meet with him, asking him to write the true teachings of the Islamic religion, so that they could guard the feelings of the Muslims after they understood 
these teachings. So he wrote a small pamphlet, which he named 'Only Allah is my Lord'. He surrendered this pamphlet to them, and the original was copied off and disseminated secretly among the Islamic community, because the pamphlet that was surrenedered to the Japanese was just for their own use!

My father and my teacher, Sheikh Abdul Karim Amrullah, passed away two months before the Indonesian nation proclaimed its independence, namely on 21 June 1945, at the age of 68. He did not leave behind any wealth for us his children, any inheritance that we could divide among ourselves following Islamic inheritance law, but he left behind a spiritual wealth that was great for the Muslim community, namely his students and the students of his students. Among them were three great men who are now struggling to further his dreams, namely Sheikh Abdul Hamid Hakim in Padang Panjang, Sheikh Ahmad Rasyid [Sutan] Manshur, Head of Muhammadiyah, and Madam Rahmah El-Junusiyah, the famous Islamic educator.

\section{Sheikh Mohammad Jamil Jambek}

Even though his colleagues had passed away one by one, and he lived alone and was already old, however he still did not stop pushing forward the struggle to give guidance to the Indonesian community in Minangkabau [West Sumatra], where they came to him with questions, asked him for fatwas and blessings. He was still able to join in the launch of the Great Indonesian Revolution of 1945. Even though he was approaching 80 years old, he was still able to give a spiritual contribution to the revolution. One of his children, he turned over to the army, and this man reached the rank of Colonel. ${ }^{26}$ And he founded a Fighting Force named 'Sabilillah', and he himself held its leadership. Even though he did not join in going to the field of battle, yet all the fighters who were going to set out would collect themselves beforehand at his school and ask for his fatwa. And he would collect aid and goods from villagers to send to the battle front. Because of his hard work, even though his age was already quite advanced, he passed away on 31 December 1947, from being stricken by pneumonia.

\section{Sheikh Thaher Jalaluddin}

There was also Sheikh Thaher Jalaluddin, the first pioneer of Abduh's ideas in the Malay and Indonesian lands, who was the oldest of all of them in age, 
and was the first to take a step and the last to pass away. After he went back to the Malay Peninsula in 1924, he returned to his homeland one more time in 1927. As soon as he arrived, he was immediately arrested by the Dutch and thrown into jail for close to a year. But because there was not enough evidence for the accusation, he was freed again and returned to Malaya. Upon arriving there, he did not stop in his activities and struggle. He led the newspaper Saudara [Brother] at Pulau Pinang and put out books on religion and taught on theology. Sometimes he would be in Singapore, sometimes in Pulau Pinang and sometimes in Kuala Kangsar, Perak, with his children, until old age. And so, in October 1956, he passed away at the age of 97 years old.

\section{Sheikh Ahmad Hassan}

The one who is still alive, thanks be to God, is Sheikh Ahmad Hassan, in Bangil. He was the youngest and of them and the last one to appear on the scene with his Persatuan Islam in 1928. He was the best of stewards among the best of companions. He continued their struggle and lived in Bangil, writing and publishing his own works himself and distributing them to the public, especially those among his loyal followers. But for the last several years, he has been ill in his leg, so that half of his leg had to be cut off and replaced with a wooden leg. But this replacement leg does not influence his activities in spreading Islam, and if it comes to exchanging ideas and debating, in the face of his opponents, his opponents always bow down in defeat or recognizing they were wrong. The incident of Sheikh Jar-ul Lah azZamachsyari, the author of the Al-Kasysyaf exegesis, is famous. His heart was strong, his arguments were strong, and his critiques were bitter, if he was facing his colleague honestly. But it reached a point where Sheikh Zamachsyari, if he merely heard the wooden leg coming from afar, would already start saying, 'He has come again! What else is it that he wants to debate?'

May God extend his years to defend Islam and fight stagnation and antiquation, combatting blind obedience.

\section{CONCLUSION}

I am already almost finished with this speech, which I am giving in Arabic, not the Indonesian tongue! I have done this work so that I could speak to you gentlmen's hearts in using this language to the best of my ability. I hope that all of you, my brothers, will show grace to me if I have said things less 
than perfectly. I hope that my love for this language can cover over any deficiencies, because Arabic is a language that first flowed into my ear before I ever heard my mother tongue. This was because when the nurse first told my father that he had a son and I was taken to him, he spoke into my ear straight away 'Allahu Akbar - Allahu Akbar, La Ilaha IIl-Allah.'27

And after I had grown up, he taught me to read the Qur'an. If I was forced, then with his scolding improving my pronunciation I have come to love Arabic and the Arab people, and I am reminded of the poem of Sayyid Mustafa Ghalayini, the late Mufti of Beirut:

People ask: do you love the Arabs? I answer: Truly I love them.

This is a love that asks for my blood and my youth.

Even if I suffer greatly on the basis of that love,

I will receive it patiently, and its Greatness will fulfill my cup.

That is their story, respected gentlemen, the people who have spread the teachings and the thought and the dream of Sheikh Muhammad Abduh in our homeland, the land of the Malays and Indonesia. And I, in fact, am one of them. It is only the English and Dutch colonialism which divided us, and now both [Indonesia and Malaya] are free and have begun to meet again in this environment of freedom. So the ideas of Muhammad Abduh are winning more and are more firmly planted as time goes on, from day to day and year to year. The people and groups who opposed it before, now are secretly following it, even though sometimes they deny it publicly. And this is the truth, and the truth is greater than the hatred and division of mankind.

And I am not stretching the truth if I say that Sayyid Jamal al-Din alAfghani and Sheikh Muhammad Abduh and Sayyid Rashid Rida, in addition to Sayyid Abdur Rahman el-Kawakibi and Emir Shakib Arslan and others have made a contribution — and not a small one - to the development of the Indonesian people and the building of an Islamic spirit, such that there has been shaped an Islamic ideology that is progressive, as part of the Indonesian nation's struggle, and the leaders of this ideology are not left behind by the leaders of our nation who only received a Dutch education. Thus, we have achieved the independence of Indonesia and we became free from colonialism on 17 August 1945.

I ask God (may He be glorified and exalted) that He would give a chance for you gentlemen to come to our nation some time in the future, our nation which has been blessed with a beautiful natural environment, fertile land and comfortable climate. It is always spring, with no excessive hot season and no 
excessive cold season. In that place you gentlemen would witness in every place, in every office and every activist of the Islamic movement, in every Islamic school and Islamic organization, hanging there a picture of Sheikh Muhammad Abduh in a special place. And his name is not far from the lips of every person who knows the meaning of the struggle for the development of Islam. If Chadewi Abbas Helmi pushed him out of the palace in 1905, and he passed away in Alexandria, he left behind mourning and a scar in the hearts of the Muslim community from East to West, and the soul of his teachings and dream have been reborn from the grave and have flown proudly flapping and have finally perched in those green and fertile islands, which are strung around the equator, which Multatuli, a Dutch poet, called 'The Emerald Necklace' and other poets have called 'The Diamond Pendant around the Neck of Asia', and I call 'A Portion of Heaven Placed on Earth'.

There, in that beautiful and verdant land, there have risen the ideas of the Teacher of the Faith, Muhammad Abduh, whom we make our model in our struggle to face life and defend the teachings of Islam. There, in my homeland which I love, Indonesia!

The Muslim community of Indonesia generally and those who praise the goals of Muhammad Abduh specifically, have been made happy because of the visits of several great Egyptians, and they have witnessed themselves the controversy over those goals, both on Sumatra or on Java. Since the coming of Dr Sheikh Abdur Rahman Taj, the Friday preacher of al-Azhar, and his entourage, and then with the coming of Sayyid Anwar Sadat, the General Secretary of the Islamic Conference, and later the Egyptian Cultural Mission composed of great experts in Egyptian thought, among them Dr Osman Amin, the great researcher of the biography of Sheikh Muhammad Abduh. Please come again and be welcomed again. We are not a nation that is hard to get along with; just with the phrase 'Assalaamu 'alaikum' you have the very key to our hearts!

And so as a closing to this speech, I hope that this closing is pleasing to all of you, I will express my thanks to the Islamic Conference and its General Secretary Sayyid Anwar Sadat, and also to his assistants and staff who have opened up this opportunity for me to travel to Egypt in its new and glorious era now. And when we met in the Asy-Syubbanul Muslimun building on this great night, my gratitude increased because I also had the chance to meet with the Head, the famous fighter General Saleh Harb. And several leading ulama were assembled there, too, especially Sahibul Fadhila Sheikh Mahmoud 
Syaltut, the assistant Friday minister at al-Azhar, and Sahibul Fadhilah Dr Sheikh Abdullatief Drazz and others. And we met there with professors and important experts in philosophy. And all of these important events took place because of the work of the Egyptian ambassador to Indonesia, Sayyid Ali Fahmi al-Amrousi.

And this visit has reached its apex when I was able to witness that one corner of the Islamic world that had been lost to us for 75 years, that is the Suez Canal, has come back into the hands of Egypt, and so has come back into Muslim hands, 'Hazihi bidha'atuna ruddat ilaina'. (This is our inheritance, which has come back into our hands.) And this is because of the policies of the Leader and President of Egypt, Jamal Abdel Nasser!

And after the Suez Canal returned with ease granted by God, I have faith that God will grant us ease, as well, in the near future, that is in the return of West Papua to the motherland of Indonesia.

Lord willing!

Long live Indonesia!

Love live Egypt!

\section{END NOTE}

1 F. Poeradisastra, ' Memang, kebenaran harus tetap disampaikan,' in Nasir Tamara, Buntaran Sanusi, and Vincent Djauhari (eds), Hamka di mata hati umat (Jakarta: Sinar Harapan, 1983), p. 158, quoted in Annette Damayanti Lienau, 'Comparative literature in the spirit of Bandung: script change, language choice, and ideology in African and Asian literatures (Senegal \& Indonesia)', PhD. dissertation, Yale University, 2011, p. 112.

2 M. C. Ricklefs, Islamisation and its opponents in Java, c. 1930 to the present (Singapore: NUS Press, 2012), p. 53.

3 Jeffrey Hadler, 'Home, fatherhood, succession: three generations of Amrullahs in twentieth-century Indonesia,' Indonesia, volume 65 (1998), p. 137.

4 Lienau, pp. 131-32 and 290 n. 294.

5 Karel Steenbrink, 'Hamka (1908-1981) and the Integration of the Islamic Ummah of Indonesia', Studia Islamika, vol. 1, number 3 (1994), p. 140.

6 Lienau, pp. 121-22.

7 Anke von Kügelgen, 'Abduh, Muhammad,' Encyclopaedia of Islam, THREE (Leiden: Brill, 2007), available at: http://referenceworks.brillonline.com/entries/encyclopaedia-of-islam-3/abduh-muhammad-COM_0103.

8 Albert Hourani, Arabic thought in the liberal age, 1798-1939 (Cambridge: Cambridge University Press, 1983), p. 139.

9 A.H. Johns, 'Qur'anic exegesis in the Malay-Indonesian world: An introductory survey', in Abdullah Saeed (ed.), Approaches to the Qur'an in contemporary Indonesia (Oxford: Oxford University Press in association with the Institute for Ismaili 
Studies, 2005) p. 34.

10 Steenbrink, p. 140.

11 Cf. Deliar Noer, The modernist Muslim movement in Indonesia, 1900-1942 (Singapore: Oxford University Press, 1973).

12 This translation has been made from the published text found in Hamka, Pengaruh Muhammad Abduh di Indonesia: Pidato diutjapkan sewaktu akan menerima gelar doctor honoris causa dari Universitas Al Azhar di Mesir pada tgl. 21 Djanuari 1958 (Jakarta: Tintamas, 1961). This publication was not copyrighted and is in the public domain.

13 Within Sufism, a common belief holds that the carnal aspect of self must die-a process achieved through a variety of mystical practices in the different ordersin order to truly experience the divine while on earth.

14 'Gates of interpretation' (Ar. bab al-ijtihad) is the traditional Islamic euphemism for the opportunity to derive one's own religious interpretations directly from revelation, i.e., the Qur'an and hadith. Those who believed that only those great teachers in the first centuries of Islam had the capacity to perform this kind of fundamental interpretation follow the doctrine of taqlid (translated above as 'blind obedience'), and in Sunni Islam they adhere to one of the four schools of jurisprudence, in South East Asia usually the Shafi'i school.

15 The Mahdi, or saviour, is a orthodox part of Islamic eschatology as the leader of the Muslim community who will restore justice before the day of judgement, but many men throughout history have claimed this title as part of an armed movement to usher in the end times, thus leading to colonial unease.

16 This last was Hamka's father.

17 At the time of this speech, Hatta had recently stepped down as Indonesia's vicepresident, but remained a great moral authority, especially for those from outside Java.

18 Before saying of the five daily ritual prayers, it had been customary to recite a formula in Arabic to the effect of 'I now intend to pray.'

19 In Islamic jurisprudence, a couple is not allowed to remarry after divorcing unless the woman has been married to another man in the intervening time. To meet this requirement on paper and facilitate a remarriage, temporary marriages were sometimes contracted in which it was agreed in advance when they would end.

20 The concept of 'Unity of Existence' (Ar. wahdat al-wujud) derives from the $12^{\text {th }}$, $13^{\text {th }}$ century philosopher Ibn Arabi. In very coarse terms, the philosophy states that only God is transcendent and has true existence, and all other things are manifestations of the divine transcendence. It has been criticized for affiliating all things with God and denying the existence of God's creation.

21 As part of his duties as Mufti of Egypt, Abduh responded to an inquiry from a Muslim in what is today South Africa, saying that wearing European-style clothing (such as wide-brimmed hats) was permissible for Muslims. This decision was attacked by his detractors for diverging from the Hanafi school of jurisprudence (the school most widely followed in Egypt).

22 In 1881, a Sudanese Muslim named Muhammad Ahmad bin Abdullah inaugurated a rebellion against his Egyptian and Ottoman overlords, claiming himself 
to be the saviour promised in Islamic eschatology. This rebellion lasted until finally conquered by the British in 1898.

23 After the destruction of the Ottoman Empire, the institution of the caliph, supposed to be the spiritual leader of all Muslims and a title the Ottoman emperors claimed, was eliminated. This led to a series of conferences looking to re-establish the institution and debating how it could be revived.

24 Footnote from the original: At this time there have been established also a Faculty of Instruction and Education in Jakarta and a Tabligh Academy in Yogyakarta. - Publisher

25 This is very flagrantly not true, among other reasons because it ignores the existence of Indonesia's other, larger mass Islamic organization, Nahdlatul 'Ulama (NU). At the time of this speech $\mathrm{NU}$ was a political party in addition to a social organization, and perhaps for this reason or perhaps out of old-fashioned rivalry Hamka seems to have elided its significantly greater membership.

26 This son, Col. Dahlan Jambek, became famous for his leadership in the Revolution and death in the Pemerintah Revolusioner Republik Indonesia rebellion of 1958-61.

27 'God is greatest - God is greatest, there is no God but God.' This is the Muslim profession of faith.

\section{Bibliography}

Hadler, Jeffrey. 1998. 'Home, fatherhood, succession: three generations of Amrullahs in twentieth-century Indonesia', Indonesia, Vol. 65, p. 122-154.

Hamka, 1961. Pengaruh Muhammad Abduh di Indonesia: Pidato diutjapkan sewaktu akan menerima gelar doctor honoris causa dari Universitas Al Azhar di Mesir pada tgl. 21 Djanuari 1958. Jakarta. Tintamas.

Hourani, Albert. 1983. Arabic thought in the liberal age, 1798-1939. Cambridge: Cambridge University Press.

Johns, A. H. 2005. 'Qur'anic exegesis in the Malay-Indonesian world: an introductory survey'. In Abdullah Saeed (ed.), Approaches to the Qur'an in contemporary Indonesia. Oxford: Oxford University Press in association with the Institute for Ismaili Studies.

Lienau, Annette Damayanti. 2011. 'Comparative literature in the spirit of Bandung: script change, language choice, and ideology in African and Asian literatures (Senegal \& Indonesia)'. PhD. Dissertation. Yale University.

Noer, Deliar. 1973. The modernist Muslim movement in Indonesia, 1900-1942. Singapore: Oxford University Press.

Poeradisastra, F. 1983. 'Memang, kebenaran harus tetap disampaikan'. In Nasir Tamara, Buntaran Sanusi, and Vincent Djauhari (eds), Hamka di mata hati umat. Jakarta: Sinar Harapan, pp. 155-164.

Ricklefs, M. C. 2012. Islamisation and its opponents in Java, c. 1930 to the present. Singapore: NUS Press.

Steenbrink, Karel. 'Hamka (1908-1981) and the Integration of the Islamic Ummah of Indonesia'. Studia Islamika, 1 (3) (1994): 119-147.

Von Kügelgen, Anke. 2007. Abduh, Muhammad. Encyclopaedia of Islam, THREE. Leiden: Brill. 